\title{
Hemispheric Contrast of Inorganic Chlorine Partitioning in the Polar Lower Stratosphere during Ozone Recovery Period Observed from Space
}

\author{
Sachiko Hayashida ${ }^{1}$ and Takafumi Sugita ${ }^{2}$ \\ ${ }^{1}$ Nara Women's University, Nara, Japan \\ ${ }^{2}$ National Institute for Environmental Studies, Tsukuba, Japan
}

\begin{abstract}
The time evolution of two major chlorine reservoirs, $\mathrm{HCl}$ and $\mathrm{ClONO}_{2}$, in the polar lower stratosphere for both hemispheres in late spring and early summer was analyzed by utilizing satellite measurements. Analysis of the collocated $\mathrm{ClONO}_{2}$ observed with ILAS, and $\mathrm{HCl}$ observed with HALOE indicated that Cly was mostly in the form of $\mathrm{HCl}$ in the Antarctic vortex in November 1996, while more than half was $\mathrm{ClONO}_{2}$ in the Arctic vortex in March 1997. The analysis of $\mathrm{N}_{2} \mathrm{O}$ indicates that there was strong subsidence of the air inside the Antarctic vortex. The vortex remnant with HCl-rich air persisted in December 1996 even after the vortex weakened, suggesting slow mixing in the boundary. The $\mathrm{ClONO}_{2} /$ Cly ratio was about 0.3 , which was derived from analysis of correlation with $\mathrm{N}_{2} \mathrm{O}$, as a representative value for the extravortex air and upper air inside the vortex (with potential temperature greater than $\sim 600 \mathrm{~K})$ in both hemispheres in spring.
\end{abstract}

\section{Introduction}

Inside the polar vortex in winter, heterogeneous reactions that proceed on polar stratospheric clouds (PSCs) convert inactive chlorine reservoirs to active forms of chlorine. When the active chlorine is deactivated back to chlorine reservoirs, the relative ratio of the two major chlorine reservoirs, hydrochloric acid $(\mathrm{HCl})$ and chlorine nitrate $\left(\mathrm{ClONO}_{2}\right)$, controls the effectiveness of stratospheric inorganic chlorine $(\mathrm{Cly})$ in ozone destruction in the lower polar stratosphere during the ozone recovery period, because $\mathrm{ClONO}_{2}$ is easy to decompose when exposed to solar ultraviolet radiation, leading to catalytic ozone destruction (Toumi et al. 1993), while $\mathrm{HCl}$ is a comparatively benign form of chlorine.

In the Antarctic "ozone hole" ozone is almost completely depleted. Besides, the vortex air is often significantly denitrified. Under such condition, $\mathrm{NO} / \mathrm{NO}_{2}$ and $\mathrm{Cl} / \mathrm{ClO}$ ratios shift toward $\mathrm{NO}$ and $\mathrm{Cl}$ (Prather and Jaffe 1990). As a result, the active chlorine in the Antarctic vortex is mostly converted into $\mathrm{HCl}$ via the reaction of $\mathrm{Cl}$ with methane, $\mathrm{Cl}+\mathrm{CH}_{4} \rightarrow \mathrm{HCl}+\mathrm{CH}_{3}$. On the other hand, under moderate ozone destruction, the $\mathrm{NO} / \mathrm{NO}_{2}$ and $\mathrm{Cl} / \mathrm{ClO}$ ratios shift toward $\mathrm{NO}_{2}$ and $\mathrm{ClO}$, and therefore $\mathrm{ClONO}_{2}$ forms via the third-body reaction, $\mathrm{ClO}+$ $\mathrm{NO}_{2}+\mathrm{M} \rightarrow \mathrm{ClONO}_{2}+\mathrm{M}$.

In contrast to the Antarctic stratosphere, in the Arctic polar vortex, ozone depletion is generally moderate and the level of denitrification is much lower than in the Antarctic polar stratosphere. Under these conditions, a significant enhancement of $\mathrm{ClONO}_{2}$ inside the vortex was reported by balloon-borne measurements, airborne measurements, and from space (Hayashida

Corresponding author: Sachiko Hayashida, Department of Information and Computer Sciences, Faculty of Science, Nara Women's University, Kitauoyanishi-machi, Nara-city 630-8506, Japan. E-mail: sachiko@ics.nara-wu.ac.jp. @2007, the Meteorological Society of Japan. et al. 2007 and references therein). Antarctic and Arctic dissimilarities of deactivation processes were investigated by some earlier studies (Douglass et al. 1995; Santee et al. 1996; Michelsen et al. 1999), but globalscale measurements of $\mathrm{ClONO}_{2}$ and $\mathrm{HCl}$ over long period are limited and year-to-year variations in deactivation processes in the polar stratosphere are not yet clear.

From November 1996 to June 1997, the Improved Limb Atmospheric Spectrometer (ILAS) was successful in observing profiles of $\mathrm{ClONO}_{2}$ with ozone and ozonerelated species in both polar stratospheres (Nakajima et al. 2006). ILAS added a new record of $\mathrm{ClONO}_{2}$ for these years. During the same period with ILAS, the Halogen Occultation Experiment (HALOE) observed $\mathrm{HCl}$. Although ILAS observation period was limited to about eight months, it is possible to compare the $\mathrm{ClONO}_{2} / \mathrm{ILAS}$ and $\mathrm{HCl} / \mathrm{HALOE}$ for both hemispheres from late spring to early summer, the season during which the depleted ozone is recovering. As ILAS also measured nitrous oxide $\left(\mathrm{N}_{2} \mathrm{O}\right)$, by which one can eliminate the effect of descending motion in the vortex, a combined dataset including $\mathrm{N}_{2} \mathrm{O}$ and chlorine reservoirs can yield new information that has not been obtained before. Hayashida et al. (2007) (H2007 hereafter) reported in detail the results of Cly partitioning in the Arctic polar stratosphere during the whole winter of 1996/1997. This article focuses on the data in late spring and early summer, and reports the hemispheric contrast of Cly partitioning observed in the polar lower stratosphere during the ozone recovery period.

\section{ILAS measurements and data analysis procedures}

The ILAS was an occultation sensor onboard the Advanced Earth Observing Satellite (ADEOS), and monitored profiles of ozone, $\mathrm{N}_{2} \mathrm{O}, \mathrm{ClONO}_{2}$, and other ozone-related species with height intervals of $1 \mathrm{~km}, 14$ times daily. The latitudinal coverage of ILAS was limited $\left(56.6-72.4^{\circ} \mathrm{N}\right.$ and $64-87.9^{\circ} \mathrm{S}$; Fig. 1a), but it observed inside and outside polar vortex frequently. Version 7 (V7) of ILAS dataset was used, in which aerosol and gas species were retrieved simultaneously, and the quality of gas species data was considerably improved especially in PSC scenes (Oshchepkov et al. 2006).

To examine the chlorine partitioning, we also analyzed $\mathrm{HCl}$ data observed with HALOE (Version 19; Russel et al. 1996) with the ILAS $\mathrm{ClONO}_{2}$ data. Occultation events of both sensors were considered collocated if the distance between the two events was less than 300 $\mathrm{km}$ and if the time difference between the two observations was less than $12 \mathrm{~h}$. Differences in the latitudinal coverage of measurements limited the period of coincident measurements. The details of the data used in this analysis are summarized in Table 1.

For data analyses, all data were categorized to inside, boundary, and outside the polar vortex when the polar vortex can be regarded as persistent. Inner and outer boundaries of the polar vortex were determined as by Nash et al. (1996). 
Table 1. A Summary of Coincident Measurements for Each Period From November 1996 to June 1997.

\begin{tabular}{ccccc}
\hline & Symbol & Period yy $/ \mathrm{mm} / \mathrm{dd}$ & Latitude range & $\mathrm{N}^{1}$ \\
\hline \multirow{3}{*}{$\mathrm{SH}^{2}$} & $\mathrm{~S}-\mathrm{I}$ & $96 / 11 / 19-96 / 11 / 24$ & $67.3^{\circ} \mathrm{S}-69.8^{\circ} \mathrm{S}$ & 40 \\
\cline { 2 - 5 } & $\mathrm{S}-\mathrm{II}$ & $96 / 12 / 09-96 / 12 / 16$ & $67.0^{\circ} \mathrm{S}-62.1^{\circ} \mathrm{S}$ & 41 \\
\cline { 2 - 5 } & $\mathrm{S}-\mathrm{III}$ & $97 / 01 / 28-97 / 01 / 31$ & $71.5^{\circ} \mathrm{S}-67.5^{\circ} \mathrm{S}$ & 19 \\
\hline & $\mathrm{N}-\mathrm{I}$ & $97 / 03 / 24-97 / 04 / 02$ & $65.4^{\circ} \mathrm{N}-69.1^{\circ} \mathrm{N}$ & 64 \\
\cline { 2 - 5 } $\mathrm{NH}^{3}$ & $\mathrm{~N}-\mathrm{II}$ & $97 / 05 / 13-97 / 05 / 14$ & $60.4^{\circ} \mathrm{N}-61.9^{\circ} \mathrm{N}$ & 12 \\
\cline { 2 - 5 } & $\mathrm{N}-\mathrm{III}$ & $97 / 06 / 16-97 / 06 / 18$ & $54.3^{\circ} \mathrm{N}-59.2^{\circ} \mathrm{N}$ & 14
\end{tabular}

${ }^{1}$ Number of coincident data, ${ }^{2}$ Southern Hemisphere,

${ }^{3}$ Northern Hemisphere
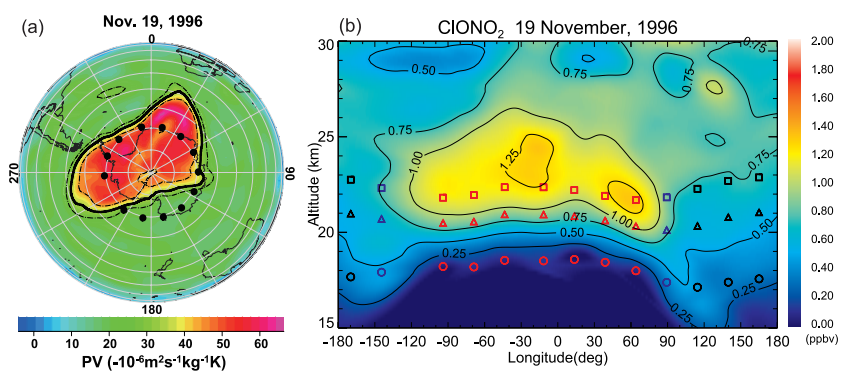

Fig. 1. a: Potential vorticity and ILAS measurement locations on November 19, 1996 on the $475 \mathrm{~K}$ isentropic surface. MetO assimilated data are used to calculate potential vorticity. Lines indicate vortex boundaries determined by the method of Nash et al. (1996). b: Longitude-altitude cross-section of $\mathrm{ClONO}_{2}$ observed with ILAS on the same day with Fig. 1a. Three isentropic surfaces are indicated by symbols. Circles, triangles, and rectangles indicate $475 \mathrm{~K}, 550 \mathrm{~K}$, and $600 \mathrm{~K}$, respectively. Red, blue, and black marks indicate inside the vortex, vortex boundary, and extravortex, respectively.

\section{Results}

Figure $1 \mathrm{~b}$ shows an example of a $\mathrm{ClONO}_{2}$ distribution observed on November 19, 1996. The corresponding ILAS locations are indicated in Fig. 1a. Figure $2 \mathrm{a}-\mathrm{c}$ shows time series of the $\mathrm{ClONO}_{2}$ and ozone volume mixing ratios (VMRs) observed with ILAS for the Southern Hemisphere (SH) polar stratosphere from November 1996 to February 1997. ILAS observed latitudes at around $68^{\circ} \mathrm{S}$ in November but higher latitudes (about $75^{\circ} \mathrm{S}$ ) in February. For comparison, the time series of $\mathrm{HCl}$ observed with $\mathrm{HALOE}$ at the latitudes south of $60^{\circ} \mathrm{S}$ are also shown at the bottom of the three panels for each isentropic surface. Figure $2 \mathrm{~d}-\mathrm{f}$ shows similar results for Northern Hemisphere (NH) from March to June 1997. Latitudinal coverage was about 68 ${ }^{\circ} \mathrm{N}$ in March, and $57^{\circ} \mathrm{N}$ in June. The time series of $\mathrm{HCl}$ for $\mathrm{NH}$ are shown for the latitudes north of $60^{\circ} \mathrm{N}$.

To eliminate the descending effect on the time evolution of chlorine species on the isentropic surface, chlorine partitioning was analyzed with respect to $\mathrm{N}_{2} \mathrm{O}$. Though ILAS has no information of $\mathrm{ClO}$ (or $\mathrm{Cl}_{2} \mathrm{O}_{2}$ ), formation of active chlorine must have been suppressed in the season that this study targeted. Here, we regarded the summation of the two reservoirs $\left(\mathrm{HCl}+\mathrm{ClONO}_{2}\right)$ as Cly approximately and examined the $\mathrm{N}_{2} \mathrm{O}$-Cly correlation. Figure 3 depicts the correlation of $\mathrm{N}_{2} \mathrm{O}$ and $\mathrm{HCl}+$ $\mathrm{ClONO}_{2}$ observed in January 1997 for SH (period S-III) and in June 1997 for $\mathrm{NH}$ (period N-III). The $\mathrm{N}_{2} \mathrm{O}-\mathrm{Cly}$ relation is similar to the results from Bonne et al. (2000) (orange line) derived from airborne measurements of chlorine species in June 1997 over NH. The difference between ILAS and Bonne's correlation may be attributed to systematic negative bias in $\mathrm{ClONO}_{2} / \mathrm{ILAS}$ (H2007), or partly to negative bias in $\mathrm{HCl} / \mathrm{HALOE}$ (Froidevaux et al. 2006). Although there is considerable uncertainty in the $\mathrm{N}_{2} \mathrm{O}$-Cly correlation shown in Fig. 3, this correlation is compact enough to be utilized to eliminate the effect of descending motion.

To examine the ratio of the two reservoirs, we defined the ratio $\mathrm{R}=\mathrm{ClONO}_{2} / \mathrm{Cly}\left(\mathrm{Cly}=\mathrm{ClONO}_{2}+\mathrm{HCl}\right)$ for the coincident events of ILAS and HALOE. Figure $4 \mathrm{a}-\mathrm{c}$ depicts the correlation of $\mathrm{N}_{2} \mathrm{O}$ and $\mathrm{R}$ observed in November 1996 (a), December 1996 (b), and January 1997 (c) for the SH, respectively. Data were categorized according to the vortex situation when vortex persisted, as in Fig. 2. Figure $4 \mathrm{~d}-\mathrm{f}$ shows also the $\mathrm{N}_{2} \mathrm{O}-\mathrm{R}$ correlation for the NH. Enhancement of $\mathrm{ClONO}_{2}$ inside the vortex is evident (see also $\mathrm{N}_{2} \mathrm{O}-\mathrm{ClONO}_{2}$ correlation in Fig. 3 of H2007). Figure $4 d-f$ indicates transition from chemically perturbed situation to the NH background situation of chlorine partitioning.

\section{Discussion}

NOAA Climate Prediction Center (CPC) SH Winter Bulletin (WB) reported that the ozone hole of 1996 was characterized by extremely low ozone (near 100 DU) and by long persistency of the polar vortex until early December. As shown in Fig. $2 \mathrm{a}-\mathrm{c}$, ozone mixing ratios inside the vortex were much lower (by more than 2 ppmv) than those outside the vortex in November 1996 on all isentropic surfaces. In particular, ozone is almost depleted on $475 \mathrm{~K}$ in the vortex, and therefore the $\mathrm{Cl} / \mathrm{ClO}$ ratio must have shifted toward $\mathrm{Cl}$ there. The $\mathrm{HCl} / \mathrm{HALOE}$ time series also verified that $\mathrm{HCl}$ formed preferentially at the $475 \mathrm{~K}$ level inside the polar vortex as observed in November and December.

For the period S-I, two branches are evident in the $\mathrm{N}_{2} \mathrm{O}$-R scatter plot shown in Fig. 4a: one for vortex air and one for extravortex air. Low values of $\mathrm{N}_{2} \mathrm{O}$ VMR (< $90 \mathrm{ppbv}$ ) in the vortex air (red) indicate a strong subsidence of the upper air that involves lower $\mathrm{N}_{2} \mathrm{O}$ VMR, while the extravortex air (shown in gray) contains more $\mathrm{N}_{2}$ O. Boundary data (blue) are in between the two branches. On $475 \mathrm{~K}$, shown by a solid line in Fig. 4a, Rvalues inside the vortex were extremely low (less than 0.01); almost all Cly was in the form of $\mathrm{HCl}$ inside the vortex. The wide span of $\mathrm{N}_{2} \mathrm{O}$ on the same isentropic surfaces (see isentropic surface lines in Fig. 4 for the period S-I) indicates that mixing on the isentropic surfaces was slow, and vortex air was strongly isolated.

In the period S-II (Fig. 4b), vortex air and extravortex air were not identified, because polar vortex was already weakened. However, two branches are still clear in the $\mathrm{N}_{2} \mathrm{O}-\mathrm{R}$ scatter plot; vortex air remnant persisted even after the vortex diminished. The isentropic lines in Fig. $4 \mathrm{~b}$ indicate a persistent wide span of $\mathrm{N}_{2} \mathrm{O}$ VMRs between the vortex and the extravortex air masses for about three weeks on the same isentropic surfaces, which again confirmed that isentropic mixing in the vortex edge region was slow.

Michelsen et al. (1999) analyzed Cly-partitioning data from airborne observations coupled with observations from space in October and November 1994. They concluded that $\mathrm{Cly}$ recovered completely into $\mathrm{HCl}$ in the Antarctic polar vortex, and an unusually high ratio of $\mathrm{HCl}$ to Cly (>0.9) was maintained while the vortex air was strongly isolated. Their results are consistent with the results presented in this article. However, the polar vortex persisted longer in 1996 than in 1994; the date of vortex disappearance was on the daynumber of 338 in 1994 while 350 in 1996 according to NOAA (2006). Our analysis revealed that even in December, one month later than the period that Michelsen et al. (1999) reported, an unusually high $\mathrm{HCl} / \mathrm{Cly}$ ratio $(>0.9)$ was 

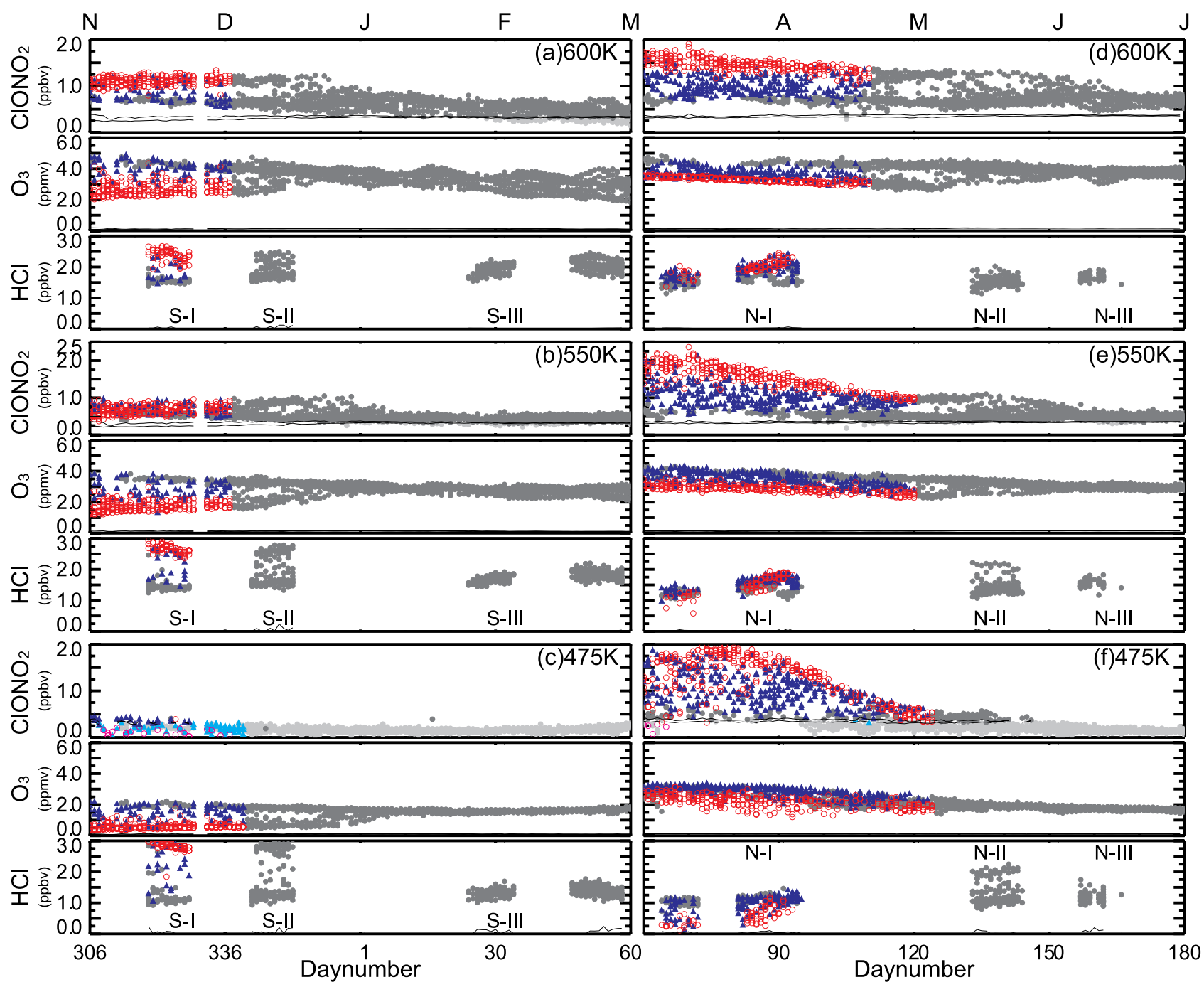

Fig. 2. a-c: Time series of the mixing ratios of $\mathrm{ClONO}_{2}$ (top panel), ozone (middle panel) observed with ILAS, and $\mathrm{HCl}$ (bottom panel) observed with HALOE for the SH from November 1996 to February 1997 on isentropic surfaces of $600 \mathrm{~K}$ (a), $550 \mathrm{~K}$ (b), and $475 \mathrm{~K}$ (c). All data are categorized inside (red), outside (gray), and in the boundary (blue) of the polar vortex when the vortex was determined. Thin lines indicate error levels of the $\mathrm{ClONO}_{2}$ data, and the values lower than the error levels are shown with light colors. The $\mathrm{HCl}$ data are taken at south of $60^{\circ} \mathrm{S}$. d-f: Same as a-c, but for the $\mathrm{NH}$. The $\mathrm{HCl}$ data are taken at north of $60^{\circ} \mathrm{N}$.

maintained in the Antarctic vortex, in spite of the increase in solar radiation in December.

In contrast to 1994 and 1996, stratospheric warming was unusually early in 2002 (vortex diminishment date 320). Höpfner et al. (2004) found a pronounced increase of $\mathrm{ClONO}_{2}$ in 2002, which is a very different situation from that of 1996. However, the vertical distribution of $\mathrm{ClONO}_{2}$ shown in Fig. $1 \mathrm{~b}$ has similar features observed in 2002 before the vortex breakup (see Fig. 1 of Höpfner et al. 2004). More $\mathrm{ClONO}_{2}$ is evident at higher altitudes $(>600 \mathrm{~K})$ than at lower altitudes $(\sim 475 \mathrm{~K})$ inside the vortex. As indicated by the time series of $\mathrm{HCl}$ in Fig. 2, more $\mathrm{HCl}$ is also pronounced at $600 \mathrm{~K}$ inside the vortex, suggesting that more Cly corresponds to low $\mathrm{N}_{2} \mathrm{O}$ due to a strong subsidence of air. The $\mathrm{R}-\mathrm{N}_{2} \mathrm{O}$ diagram indicates that the upper air (low $\mathrm{N}_{2} \mathrm{O}$ ) has a similar ratio of $\mathrm{R}$ ( $\sim 0.3$ inside the vortex), with almost the same level of $\mathrm{R}$ outside the vortex. This value can be regarded as representative $\mathrm{R}$ in nonprocessed air.

In the Arctic vortex in winter of 1997, significant ozone depletion was observed; but about $3 \mathrm{ppmv}$ of ozone still remained, which is enough to result in $\mathrm{ClON}$ $\mathrm{O}_{2}$ rather than $\mathrm{HCl}$ being produced upon deactivation of active chlorine. Correlation of the $\mathrm{N}_{2} \mathrm{O}-\mathrm{R}$ observed in
March 1997 (Fig. 4d) clearly shows enhancement of $\mathrm{ClONO}_{2}$ in vortex and boundary air, which verifies the preferential $\mathrm{ClONO}_{2}$ production in the Arctic vortex. As seen in Fig. 4e, the dashed line $(550 \mathrm{~K})$ in N-II period also indicates a persistent wide span of $\mathrm{N}_{2} \mathrm{O}$ VMRs as in S-II, which suggests that isentropic mixing in the vortex edge region was also slow in the NH. In June (Fig. 4f), $\mathrm{N}_{2} \mathrm{O}$ on the $475 \mathrm{~K}$ and $550 \mathrm{~K}$ isentropic surface had narrow spans, suggesting that the mixing of vortex remnant with extravortex air was almost completed; however, the air was not yet well mixed at higher altitudes (> $600 \mathrm{~K})$.

In summer of both the hemispheres (S-III and N-III), $\mathrm{R}$-values are compared with the earlier studies. For the range of inferred $\mathrm{Cly}$ between 2.5 and $3.0 \mathrm{ppbv}$, corresponding $\mathrm{N}_{2} \mathrm{O} \sim 100$ ppbv, $\mathrm{R}$ is about 0.37 in N-III, which is almost comparable to the aircraft measurements in late spring (Bonne et al. 2000). In S-III, R is about 0.25, which is rather smaller than that in N-III. The difference could be attributed to the different conditions of the radiation field, ozone VMR, and temperature from those in N-III, because ILAS measurement latitudes shifted polewards in February (see Table 1). 


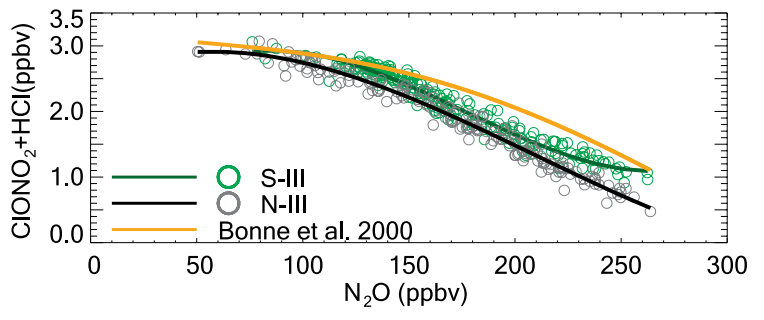

Fig. 3. Correlation of $\mathrm{N}_{2} \mathrm{O}$ and $\mathrm{Cly}\left(\sim \mathrm{HCl}+\mathrm{ClONO}_{2}\right)$ for S-III (green) and N-III (black) periods. Solid lines indicate cubic polynomial fit to the data. Orange line indicates the results observed in NH according to Bonne et al (2000).

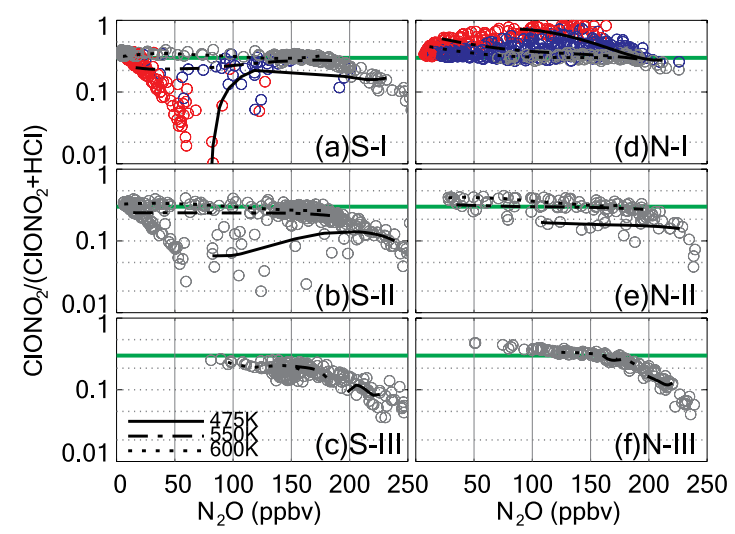

Fig. 4. a-f: Correlation of $\mathrm{N}_{2} \mathrm{O}$ and $\mathrm{R}=\mathrm{ClONO}_{2} / \mathrm{Cly}$. The details of the data used to determine the ratio are in Table 1. The solid, dashed, and dotted lines in each panel indicate cubic polynomial fit to the data observed on $475 \mathrm{~K}, 550 \mathrm{~K}$, and $600 \mathrm{~K}$ isentropic surfaces, respectively.

\section{Conclusion}

The time evolution of $\mathrm{ClONO}_{2}$ and $\mathrm{HCl}$ in the polar lower stratosphere during ozone recovering period presented a clear hemispheric contrast; Cly was mostly in the form of $\mathrm{HCl}$ in the Antarctic vortex, but in the form of $\mathrm{ClONO}_{2}$ in the Arctic vortex. The $\mathrm{ClONO}_{2} / \mathrm{Cly}$ ratio (R) was inferred from $\mathrm{N}_{2} \mathrm{O}$-Cly correlation. In the Antarctic vortex, $\mathrm{R}$ was almost zero at lower altitude $\left(\mathrm{N}_{2} \mathrm{O}>50 \mathrm{ppbv}\right)$, and the vortex remnant in which most of the Cly was in the form of $\mathrm{HCl}$ persisted even after the vortex diminished for at least three weeks. R-values approached to about 0.3 at higher altitudes $\left(\mathrm{N}_{2} \mathrm{O} \sim 0\right)$, and the R-value of 0.3 was also regarded as a representative value for the extravortex air in both hemispheres in spring.

\section{Acknowledgments}

We wish to express our immense gratitude to all the ILAS science team members and their associates. The ILAS retrieval data processing was carried out at the ILAS Data Handling Facility (DHF) at NIES. This study was partly supported by the Global Environmental Research Fund (GERF) of the Ministry of the Environment (MOE) of Japan.

\section{References}

Bonne, G. P., R. M. Stimpfle, R. C. Cohen, P. B. Voss, K. K. Perkins, J. G. Anderson, R. J. Salawitch, J. W. Elkins, G. S.
Dutton, K. W. Jucks, and G. C. Toon, 2000: An examination of the inorganic chlorine budget in the lower stratosphere. J. Geophys. Res., 105(D2), 1957-1971, doi:10.1029/ 1999JD900996.

Douglas, A. R., M. R. Schoeberl, R. S. Stolarski, J. W. Waters, J. M. Russell III, A. E. Roche, and S. T. Massie, 1995: Interhemispheric differences in springtime production of $\mathrm{HCl}$ and $\mathrm{ClONO}_{2}$ in the polar vortices. J. Geophys. Res., 100, 13967-13978, doi:10.1029/95JD00698.

Froidevaux, L. N. J. Livesey, W. G. Read, R. J. Salawitch, J. W. Waters, B. Drouin, I. A. MacKenzie, H. C. Pumphrey, P. Bernath, C. Boone, R. Nassar, S. Montzka, J. Elkins, D. Cunnold, and D. Waugh, 2006: Temporal decrease in upper atmospheric chlorine. Geophys. Res. Lett., 33, L23812, doi:10.1029/2006GL027600.

Hayashida, S., T. Sugita, N. Ikeda, Y. Toda, and H. Irie, 2007: Temporal evolution of $\mathrm{ClONO}_{2}$ observed with Improved Limb Atmospheric Spectrometer (ILAS) during Arctic late winter and early spring in 1997. J. Geophys. Res., 112, D14311, doi:10.1029/2006JD008108.

Höpfner, M., T. von Clarmann, H. Fischer, N. Glatthor, U. Grabowski, S. Kellmann, M. Kiefer, A. Linden, G. M. Tsidu, M. Milz, T. Steck, G. P. Stiller, D. Y. Wang, and B. Funke, 2004: First spaceborne observations of Antarctic stratospheric $\mathrm{ClONO}_{2}$ recovery: Austral spring 2002. J. Geophys. Res., 109, D11308, doi:10.1029/2004JD004609.

Michelsen, H. A., C. R. Webster, R. D. May, G. L. Manney, D. C. Scott, J. J. Margitan, F. W. Irion, M. R. Gunson, M. H. Proffitt, A. F. Tuck, R. M. Stimpfle, D. W. Kohn, J. G. Anderson, L. Jaegle, and C. M. Spivakovsky, 1999: Maintenance of high $\mathrm{HCl} / \mathrm{Cly}$ and $\mathrm{NOx} / \mathrm{NOy}$ in the Antarctic vortex: A chemical signature of confinement during spring. J. Geophys. Res., 104(D21), 26419-26436, doi:10. 1029/1999JD900473.

Nakajima, H., T. Sugita, H. Irie, N. Saitoh, H. Kanzawa, H. Oelhaf, G. Wetzel, G. C. Toon, B. Sen, J.-F. Blavier, W. A. Traub, K. Jucks, D. G. Johnson, T. Yokota, and Y. Sasano, 2006: Measurements of $\mathrm{ClONO}_{2}$ by the Improved Limb Atmospheric Spectrometer (ILAS) in high-latitude stratosphere: New products using version 6.1 data processing algorithm. J. Geophys. Res., 111, D11S09, doi:10.1029/ 2005JD006441.

Nash, E. R., P. A. Newman, J. E. Rosenfield, and M. R. Schoeberl, 1996: An objective determination of the polar vortex using Ertel's potential vorticity. J. Geophys. Res., 101(D5), 9471-9478, doi:10.1029/96JD00066.

NOAA, 2006: Southern Hemisphere Winter Summary 19992006, National Weather Service/National Centers for Environmental Prediction/Climate Prediction Center.

Oshchepkov, S., Y. Sasano, T. Yokota, H. Nakajima, N. Uemura, N. Saitoh, T. Sugita, and H. Matsuda, 2006: ILAS data processing for stratospheric gas and aerosol retrievals with aerosol physical modeling: Methodology and validation of gas retrievals. J. Geophys. Res., 111, D02307, doi:10.1029/2005JD006543.

Prather, M., and A. H. Jaffe, 1990: Global impact of the Antarctic ozone hole: Chemical propagation. J. Geophys. Res., 95(D4), 3473-3492.

Russell III, J. M., L. E. Deaver, M. Luo, J. H. Park, L. L. Gordley, A. F. Tuck, G. C. Toon, M. R. Gunson, W. A. Traub, D. G. Johnson, K. W. Jucks, D. G. Murcray, R. Zander, I. G. Nolt, and C. R. Webster, 1996: Validation of hydrogen chloride measurements made by the Halogen Occultation Experiment from the UARS platform. J. Geophys. Res., 101(D6), 10151-10162, doi:10.1029/95JD01696.

Santee, M. L., L. Froidevaux, G. L. Manney, W. G. Read, J. W. Waters, M. P. Chipperfield, A. E. Roche, J. B. Kumer, J. L. Mergenthaler, and J. M. Russell, 1996: Chlorine deactivation in the lower stratospheric polar regions during late winter: Results from UARS. J. Geophys. Res., 101(D13), 18835-18859, doi:10.1029/96JD00580.

Toumi, R., R. L. Jobes, and J. A. Pyle, 1993: Stratospheric ozone depletion by $\mathrm{ClONO}_{2}$ photolysis. Nature, 365, 37-39.

Manuscript received 1 August 2007, accepted 29 October 2007 SOLA: http://www.jstage.jst.go.jp/browse/sola/ 